\title{
RINGWORM BY Microsporum canis IN LONG-TAILED CHINCHILLA (Chinchilla lanigera)
}

[Dermatofitose por Microsporum canis em Chinchila (Chinchilla lanigera)]

\author{
Guilherme Augusto Marietto-Gonçalves ${ }^{1 *}$ \\ ${ }^{1}$ Universidade do Oeste de Santa Catarina -UNOESC, Campus II, Xanxerê-SC.
}

\begin{abstract}
Long-tailed chinchillas are rodents popularly bred as pets for being a docile animal; however, in the natural environment, it is a critically endangered species. This study reports the occurrence of ringworm in Chinchilla lanigera. A female specimen presenting an alopecia-oval lesion on the left cheek was send for clinical care. On examination, the lesion was positive for the Wood test and on the hematological evaluation, and in the mycological assessment was performed and Microsporum canis was isolated after 10 days of incubation on Sabouraud Dextrose Agar. The animal was treated with topical solution of chlorhexidine and iodopovedine, hydrocortisone ointment and terbinafine cream. Ringworm is an uncommon infection in rodents and M. canis is a commensal fungus of the skin of dogs, being a parasite primarily zoophilic but can cause injury to humans. Ringworms are uncommon in rodents, being attributed in this report to stress associated to indirect contact with canine material contaminated with the fungus.
\end{abstract}

Keywords: Dermatology; exotic animals medicine; mycosis; pets; rodents.

RESUMO - Chinchilas são roedores popularmente criados como animais de estimação por ser um animal dócil, porém em ambiente natural é uma espécie criticamente ameaçada de extinção. O presente artigo relata a ocorrência de dermatofitose em Chinchilla lanigera. Uma fêmea foi encaminhada para atendimento clínico apresentando uma lesão alopécica-ovalada em face esquerda. No exame clínico a lesão era positiva para o teste de Wood e na avaliação micológica sendo isolado Microsporum canis após 10 dias de incubação em Agar Sabouraud-Dextrose. O animal foi tratado com solução tópica de clorexidine e iodopovidona, pomada de hidrocortisona e creme de terbinafina. Dermatofitose é uma infecção incomum em roedores e atribuiu-se as alterações deste relato a estresse associado ao contato indireto com material cutâneo canino contaminado com o fungo.

Palavras-Chave: dermatologia; medicina de animais exóticos; micose; roedores.

\footnotetext{
* Autor para correspondência. E-mail: guilherme.goncalves@ unoesc.edu.br
} 


\section{INTRODUCTION}

Chinchilla [Chinchilla lanigera] is a mammal [Order Rodentia, Family Chinchillidae] and is commonly found in home environments as a pet, but it is a species considered critically endangered in its natural environment by the Red List of endangered animal species of IUCN (D'elia \& Teta, 2008). It is an animal originated from the Chilean Andes Mountains, living in arid and cold shrub regions between 400 and 3000 meters of altitude (Neves, 1986; Canevari \& Vaccaro, 2007).

Its creation as pet dates from 1923 in the United States, and it has been kept for decades exclusively for meat and skin (Neves, 1986), but since 1990, $C$. lanigera emerged in the Brazilian market as a pet animal due to its beauty, gentleness and easy handling.

This paper reports the occurrence of ringworm caused by Microsporum canis in $C$. lanigera diagnosed during private clinical care.

\section{CASE REPORT}

A 4-years-old female $C$. lanigera specimen weighing $470 \mathrm{~g}$, rectal temperature of $37.5^{\circ} \mathrm{C}$, was referred for clinical care with face alopecia complaint one month ago. The animal was permanently kept in cage (with two other specimens of the same species), feed with commercial rodent diet (unidentified brand) and indirect contact with dog and guinea pig [Cavia porcellus]. No other animal had lesions or history of similar lesions.

Physical analysis revealed a focal reddish oval alopecia lesion with dry appearance [Figure 1] that at touch peeled off on the edges on the left side. The animal was sedated with ketamine at dose of $30 \mathrm{mg} / \mathrm{kg}$ (Carpenter \& Marion, 2013) and then blood was collected from the tail vein by puncture and surface debridement of the lesion for cytological evaluation and Wood test. Hair and skin samples were collected for mycological culture and grown in Sabouraud-dextrose agar at $37^{\circ} \mathrm{C}$ for 10 days, as described by Quinn et al. (2004).

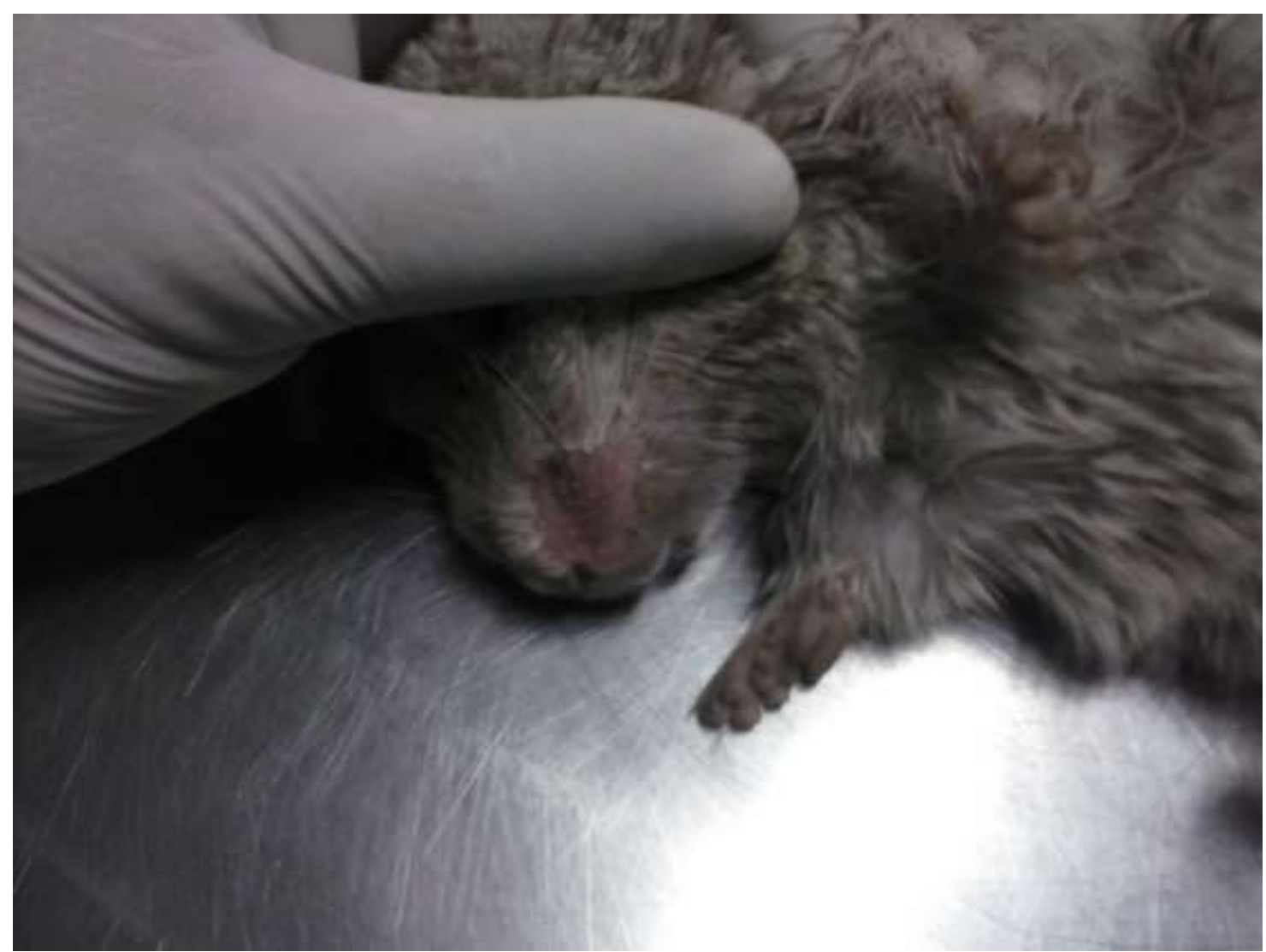

Figura 1. Chinchilla laniger showing a focal reddish oval alopecia lesion with dry appearance in left side.

Wood test showed the presence of green fluorescence in the lesion region and cytological analysis did not detect the presence of ectoparasites [scab]. Hematologic patterns were within normality values, but the percentage of eosinophils values were close to the allowed maximum limit, demonstrating a biologic tendency for eosinophilic stage [Table 1]. Microbiological examination showed growth of velvety white-yellowish colonies microscopically identified as Microsporum canis. 
Table 1. Hematological parameters presented by the Chinchilla laniger.

\begin{tabular}{lcc}
\hline \multicolumn{1}{c}{ Parameters } & Profile found & Reference values* \\
\hline Hematocrit & 38 & $35-40$ \\
Red blood cells $\left(\times 10^{6} / \mu \mathrm{L}\right)$ & 5,2 & $3,4-4,6$ \\
Hemoglobin $(\mathrm{g} / \mathrm{dL})$ & 12,2 & $11,6-14,5$ \\
Mean Corpuscular volume (fl) & 110 & $87-116$ \\
Mean corpuscular hemoglobin concentration $(\mathrm{g} / \mathrm{dL})$ & 37 & $33-38$ \\
White blood cells $\left(\times 10^{3} / \mu \mathrm{L}\right)$ & 5,2 & $4,4-6,1$ \\
Lynphocytes $(\%)$ & 35,5 & $29,6-40,5$ \\
Neutrophil $(\%)$ & 38 & $32,7-47,2$ \\
Monocytes $(\%)$ & 10,5 & $7,8-15,2$ \\
Eosinophil $(\%)$ & 7,1 & $3,9-7,6$ \\
Basophil $(\%)$ & 4,9 & $3,2-7,4$ \\
\hline
\end{tabular}

*Quesenberry et al. (2012).

The animal was treated with daily cleaning using topical solution of $2 \%$ chlorhexidine and iodopovedine, hydrocortisone ointment at $10 \mathrm{mg} / \mathrm{g}$ $\left[\right.$ Stiefcortil ${ }^{\circledR}$, Laboratórios Stiefel Ltda, GuarulhosSP] and terbinafine hydrochloride cream at $10 \mathrm{mg} / \mathrm{g}$ [Lamisil ${ }^{\circledR}$, Novartis, Taboão da Serra-SP], and the procedure was repeated three times daily during 30 days.

After 30 days of treatment, a significant improvement of the lesion was observed, with resurgence of fur in the affected region. But this growth interfered in the clinical evolution, stagnating clinical resolution process because hair is refractory to drugs applied, which prevented direct access of drugs to the affected region. To overcome the situation, trichotomy of injury and peripheral area was performed to expose the affected region. After 60 days of treatment, the lesion was absent [Figure 2]. The treatment was performed within 90 days, being finalized after two negative mycological exams, according Rosenfeld (2010).

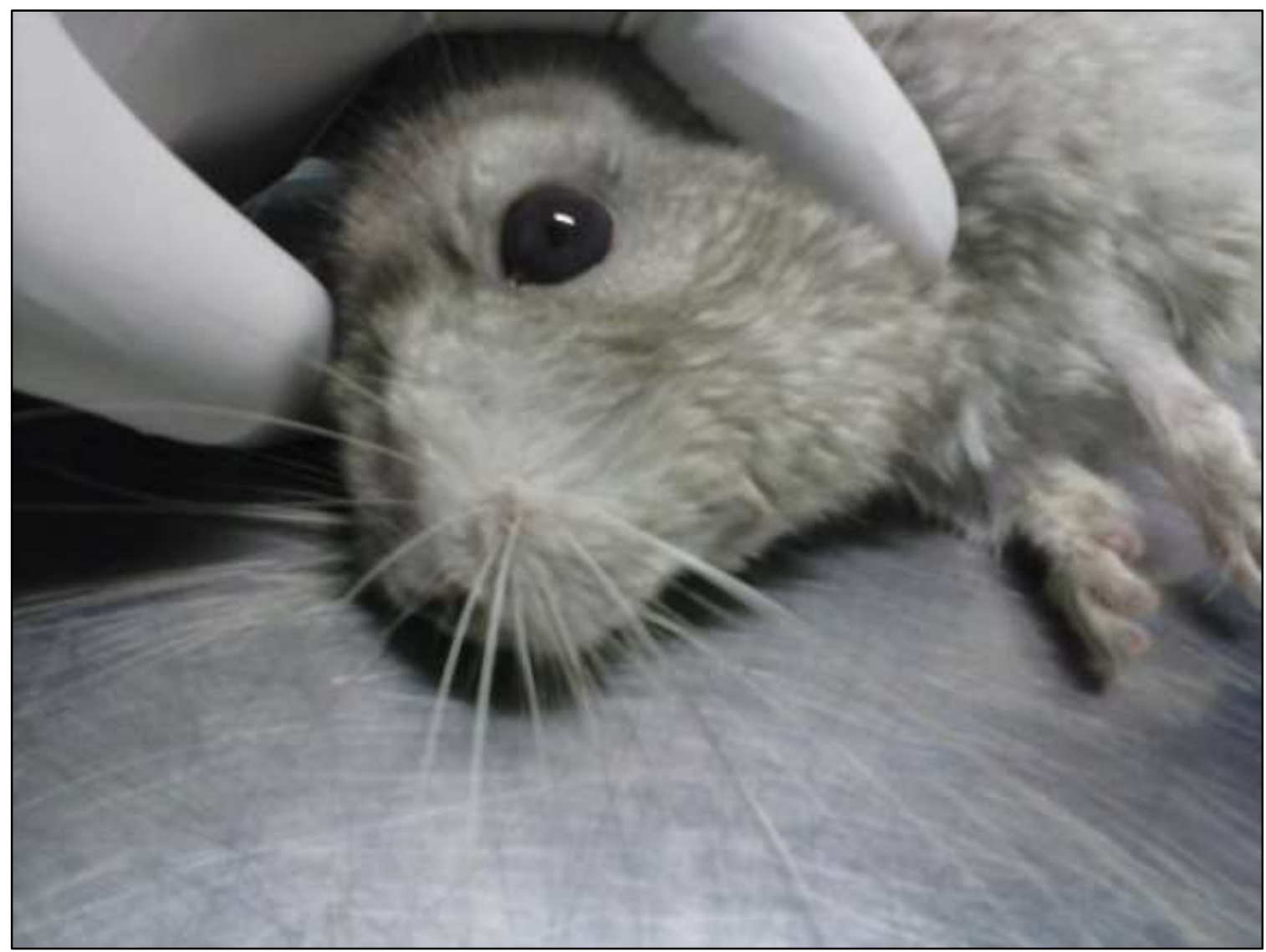

Figura 2. After 60 days of topic treatment with terbinafine the injury was absent with full recovery of pelage and vibrissae. 


\section{DISCUSSION}

In Chinchillas, the occurrence of ringworm is unusual, and similar to other rodent species, ringworm is commonly caused by Trichophyton mentagrophytes (Quinn et al., 2004; Mans \& Donnely, 2012) and Microsporum gypseum (Mans \& Donnely, 2012; Morganti \& Gomez Portugal, 1970), and T. mentagrophytes is a fungus typically isolated in healthy rodents skin (Donnelly et al., 2000).

M. canis is a zoophylic dermathophyte that causes infection in dogs, and domestic cats are common asymptomatic carriers. But less frequently, other animal species including man can be infected (Hagen \& Gorhan, 1972; Quinn et al., 2004) and a case of infection in $C$. lanigera has already been reported (Donelly et al., 2000).

Clinically, ringworm in $C$. lanigera shows small areas of alopecia with skin peeling in nostril, as well as in ears and podal ends. In chronic cases, there is a large area of inflammation and itchy scarification (Mans \& Donnely, 2012), as observed in this case. In general, dermatophyte fungi are able to colonize corneal structures without penetration in living tissue, being more common in warm and humid environments (Hargis \& Ginn, 2013), i.e., biologically, they interact little with living tissues, which justifies the normality of haematological parameters but with eosinophilic trend.

In domestic animals, the treatment is normally carried out orally or bathing with ketoconazole (Nobre et al., 2002; Rosenfeld, 2010). However, $C$. laniger is an animal that naturally ingests small amounts of water and its hair is refractory to water penetration, we chose not to perform systemic therapy due to the risk of nephrotoxicity and to the non-use of baths with shampoo added of antifungal agents due to the risk of therapeutic inefficiency. The use of terbinafine was selected for therapeutic efficacy already evaluated in small animals (Kuźner et al., 2000; Kotnik et al., 2001).

The occurrence of ringworm is related to immunosuppression (Rosenfeld, 2010), but animals kept in overcrowded and dirty environments, in addition to malnutrition, show increased susceptibility to infection. Usually, animals are infected by direct contact with infected individuals or indirectly by contact with fallen scales of infected animals (Rosenfeld, 2010; Hargis \& Ginn, 2013).

The presence of dog in the same environment was crucial for the infection of $C$. lanigera, but until then, what triggered infection had not been determined. The owner reported that the animal was originally created in the city of Curitiba-PR, Brazil, and two months before the onset of the injury, it was brought to the city of Foz do Iguaçu-PR. Curitiba maximum average peak temperature is $26^{\circ} \mathrm{C}$ and $\mathrm{Foz}$ de Iguaçu is $33^{\circ} \mathrm{C}$ (INMET, 2014). According to Neves (1986), the ideal temperature for raising chinchilla is $18^{\circ} \mathrm{C}$, tolerating up to $25^{\circ} \mathrm{C}$ and maximum humidity of $70 \%$, temperature and humidity above these values are potentially harmful.

The owner reported that he does not keep the animal in air-conditioned environment and probably high temperatures contributed to the stress condition, and combined with the constant contact with the pathogen, triggered the occurrence of $M$. canis infection in the $C$. lanigera specimen reported here. The maintenance of this animal in airconditioned environment is crucial to avoid thermal stress, which can trigger the occurrence of ringworm and other infections secondary to immunosuppression conditions.

\section{REFERENCES}

Canevari M. \& Vaccaro O. 2007. Guía de Mamíferos del Sur de América del Sur. Buenos Aires, BA, Editorial LOLA.

Carpenter J.W. \& Marion C.J. 2013. Exotic Animal Formulary. Vol. 4. St. Louis, MO, Elsevier Saunders.

D'Elia G. \& Teta P. (2008). Chinchilla lanigera. The IUCN Red List of Threatened Species, 2008. Version 2014.2. Disponível em: <www.iucnredlist.org>. Acessado em 12 de Agosto de 2014.

Donnelly T.M., Rush E.M. \& Lackner P.A. 2000. Ringworm in small exotic pets. Sem. Avian Exo. Pet Med. 9:82-93.

Hagen K.W. \& Gorham J.R. 1972. Dermatomycoses in fur animals: chinchilla, ferret, mink and rabbit. Vet. Med. Small Anim. Clin. 67: 43-48.

Hargis A.M. \& Ginn P.E. 2013. O tegumento, p. 975-1087. In: Zachary J.F. \& McGavin M.D. (ed.). Bases da Patologia em Veterinária. Vol. 5. Rio de Janeiro, RJ, Elsevier.

INMET. Normais climatológicas do Brasil 1961-1990 Temperatura maxima $\left({ }^{\circ} \mathrm{C}\right)$. Available in: <www.inmet.gov.br/portal/index.php?=clima/normaisClimatolo gicas>. Acessado em 09 de setembro de 2014

Quesenberry K.E., Donnelly T.M. \& Mans C. 2012. Biology, husbandry, and clinical techniques in Guinea pigs and Chinchillas, p. 279-294. In: Quesenberry K.E. \& Carpenter J.W. Ferrets, Rabbits and Rodents. Vol. 3. St. Louis, MO, Elseviers Saunders.

Quinn P.J., Carter M.E. \& Markey E. 2004. Clinical Veterinary Microbiology. Philadelphia, TN, Mosby.

Mans C. \& Donnely T.M. 2012. Disease problems in Chinchillas, p. 311-325. In: Quesenberry KE, Carpenter JW: Ferrets, Rabbits and Rodents. Vol. 3. St. Louis, MO, Elseviers Saunders.

Kotnik T., Eržen N.K., Kužner J. \& Marinka Drobnič-Košorok M. 2001. Terbinafine hydrochloride treatment of Microsporum 
canis experimentally-induced ringworm in cats. Vet. Microbiol. 83: $161-168$.

Kuźner J., Kožuh Erzen N. \& Drobniè-Košorok M. 2000. Determination of the terbinafine hydrochloride levels in hair of cats and children infected with Microsporum canis and treated with Lamisil ${ }^{\circledR}$ tablets. Slov. Vet. Res. 37: 107-113.

Morganti L. \& Gomez Portugal E.A. 1970. Microsporum gypseum infection in chinchillas. Sabouraudia. 8: 39-40.

Neves D.M. 1986. Criação caseira da chinchila e seu melhoramento genético. São Paulo, SP, Nobel.

Nobre M.O., Nascente P.S., Meireles M.C. \& Ferreiro L. 2002. Drogas antifúngicas para pequenos e grandes animais. Ciência Rural. 32: 175-184.

Rosenfeld A.J. 2010. Pratica Veterinária: Uma Abordagem Didática. São Paulo, SP, Roca. 